\title{
Assessment of Extension Services Delivery to Fish Farmers in South Western Nigeria
}

\author{
Apata, O.M., S.O.W Toluwase and A. O. Awoyemi \\ Department of Agricultural Economics and Extension Services, Ekiti State University, Ado-Ekiti, Nigeria.
}

\begin{abstract}
Inability of fish farmers in Nigeria to produce at a rate that can meet the population demand has been linked to lack of access to crucial information on improved fish farming technique. Information is an indispensable factor in fish farming and it is the basis of extension service delivery. This study was designed to describe demographic characteristic of fish farmers, identify sources of various information to fish farmers and identify information access constraints faced by farmers. Purposive sampling procedure was used to select 2 States and a total of 160 respondents were selected for the study. Descriptive statistics such as frequency, percentage, mean and standard deviation and Chi-Square $\left(\mathrm{X}^{2}\right)$ was used for inferential statistics. Result revealed that mean age was 44.8 years, $77.5 \%$ were male, only $7.5 \%$ have no formal education and $98.1 \%$ were full time fish farmers. About $25.0 \%$ received information frequently, $50.6 \%$ rarely while $24.4 \%$ never received information from extension agents. Inadequate of extension contact was identified by $88.8 \%$ of the respondents as information access constraint. Chi-Square analysis showed significant relationship $\left(X^{2}=13.426\right.$, $p=0.016$ ) between source of information and utilization of information.
\end{abstract}

Indexing terms/Keywords: Extension deliver, Agricultural Information, Fish Farming and Information Utilization.

Language: English

Date of Submission: 2018-03-14

Date of Acceptance: 2018-03-20

Date of Publication: 2018-03-30

ISSN: 2321-1091

Volume: 12 Issue: 1

Journal: JOURNAL OF SOCIAL SCIENCE RESEARCH

Website: https://cirworld.com

This work is licensed under a Creative Commons Attribution 4.0 International License.

\section{Introduction}

The contribution of the fishery sector to global economy and food security cannot be underestimated. The importance of fish in human nutrition as a major source of protein cannot be over emphasized as it touches the lives of a large percentage of the population in the South-Western part of Nigeria. As population increases the demand for fish and fish product increases especially with its nutritional advantage over meat. It has been reported that fish contributed 6 to 8 percent of agricultural sector's total contribution to Gross Domestic Product (GDP) (CBN, 2005). Fish contribute $40 \%$ of total dietary protein consumption and $60 \%$ of the total intake in adults especially in rural area (Adekoya and Miller, 2004). In addition, Fish production serves as means of livelihoods to millions of people worldwide (Greenfacts, 2004). Fish farming helps empower the poor and directly promote their standard of living (Obikezie, 1999). 
In 1986 , the domestic source accounted for $82 \%$ of the nation's demand for fish leaving only $18 \%$ to fish importation. However, the situation has deteriorated greatly, making fish importation to account for about $60 \%$ of the demand during 2001-2005 (Esobhawan, 2007). Nigeria is now believed to be one of the largest fish importers in the world with official records indicating an average amount of \#30 billion spent annually on fish importation.

Adereti et al (2006) stated that the quality of information rests solidly on three pillars which are: accuracy, timeliness and relevance. Accuracy implies that information is free from bias; timeliness means that recipients can get information when they need it, while relevance implies whether the piece of information specifically answers the user's question. An individual consciously or unconsciously engages in information search in order to find appropriate information which can fill the information gap there by regaining physiological and psychological balance.

Information needed by fish farmers include information on pond construction, stocking, pond management, fish breeding, credit, fish harvesting, feed formulation, group formation and marketing outlets etc. However, Agricultural extension agents carry out this particular responsibility by using various strategies to encourage farmers to adopt agricultural innovations. These strategies include establishment of farm institutes, extension work station, experimental farms, visits to farms and various types of farm settlement schemes. Each strategy has met with some amount of success but the rate of farmers' acceptance and use of Agricultural innovations is still low.

In Nigeria, fish alone contributes on the average $20-25 \%$ per caput animal intake and could be as high as $80 \%$ in coastal and riverine communities (FAO, 2000). Tobor (1992) and Ajana (2002) reported that the average annual demand for fish in Nigeria between 1995 and 2000 was estimated at 1.22 million metric tonnes and that this might increase to about 1.425 million metric tonnes by the year 2005 .

Globally, the demand for fish has continued to be on the increase, especially in the developing countries which import about 33 million tonnes of fish worth over US\$61 billion yearly. Nigeria is not left out in the struggle. According to CBN (2010), the demand for fish in the country is 1.5 million metric tonnes per annum while the domestic production is $769,680 \mathrm{mT}$, indicating that only $47.3 \%$ of the demand is secured from domestic sources, leaving a wide gap of $52.7 \%$ of the demand unsecured. As noted by Esobhawan et al (2011), about $80 \%$ of the Nigeria's demand for fish during the period of 1971 to 1980 came from domestic sources leaving just $20 \%$ to fish importation.

Amiengheme (2005) reported that fish has a nutrient profile superior to terrestrial meat being an excellent source of high quality animal protein, sulphur and essential amino acid. The flesh of fish is also readily digestible and immediately utilizable by the human body, which makes it suitable and complementary for African countries, including Nigeria, with high carbohydrate diet (FAO, 2005). Fish is relatively cheaper than meat and there is hardly any religious taboo affecting its consumption unlike pork and beef.

Adamu (2007) however, gave the actual total domestic fish production in 2005 as 579,500 tonnes, while production from aquaculture was 56,300 tonnes in the same year. Fasasi (2003) put the demand - supply gap of fish in Nigeria as 1.0 million metric tonnes while fingerlings demand - supply gap is over 500 million. According to Satia (1990), Artisanal fisheries contribute about 491 million tonnes, Aquaculture, about 57 million tonnes, Industrial (Trawler), about 33 million tonnes and Distance fishing (Imports) about 612 million tonnes. From the above analysis, less than $50 \%$ of the total annual fish consumed by Nigerians are produced locally. There is, therefore, the need not only to maximize the exploitation of our fishery resources but to concentrate more on the development of aquaculture which has the greatest potential to increase fish production for local consumption and export.

The inability of the farmers in developing countries, including Nigeria, to produce at a rate that can meet the need of the populace has been linked to lack of access to crucial information on improved agricultural practices, among other factors (ICS-Nigeria, 2005). This is exacerbated by the dearth of agricultural extension workers through whom farmers can be reached. This results from the limited resources available to the public 
extension agencies with which farmers are reached free of charge in developing countries (Budak et al 2010). Therefore, in a bid to promote farmers' access to extension services, various forms of agricultural extension finance payments have been instituted in some parts of the world, like in the United Kingdom, Netherlands, Sweden, Germany, Chile and Portugal (Budak et al. 2010; Rivera and Cary, 1997). This trend would reduce the economic burden on government and increase the efficiency and effectiveness of extension (Shekara, 2004). The trend would also enhance sustainability in fish production.

Sustainability in the context of fish farmers' willingness-to-pay for extension services is premised within the meaning of sustainability as posited by the World Commission on Environment and Development (1987): "meeting the needs of the present without compromising the ability of the future generation to meet their own needs." A positive attitude of fish farmers towards financing extensions services can enhance both ecological and socio-economic concepts of sustainability: It can make fish production levels relatively adequate for the present and future generations without reducing the ecosystem potentials. Besides, it can increase or maintain fish output to meet the social and economic needs of the actual and future generation.

Access to adequate information is therefore very essential to increase productivity. The information on fish farming or fish farming technologies needed by farmers and management breeds and fish processing's storage, marketing etc. However, in spite of research and extension service efforts on improving packages on agricultural production, they are not being adequately used by farmers. All these information on fish farming techniques, when acquired and effectively accessed and utilized by the fish farmers will help to increase culture fish production and translate to income, improve farmer's standard of living thereby leading to improvement in rural areas and by extension, the nation's economy.

\section{Objectives of The Study}

The general objective of the study was to assess extension service delivery to fish farmers in Southwestern Nigeria. The specific objectives were to: -

i. Describe the socio -economic characteristics of respondent in the study area

ii. Identify sources of information on fish farming

iii. identify extension services accessed and utilized by the respondents and;

iv. identify constraints to extension service delivery to the respondents.

Hypotheses: The following hypotheses were tested for the study:

Ho1: There is no significant relationship between socio- economic characteristics of fish farmers and extension information delivery and utilization.

$\mathrm{H}_{02:}$ There is no significant relationship between information sources and extension information delivery and utilization among fish farmers.

\section{Methodology}

Study Area: - The study was carried out in the southwest region of Nigeria. Southwest is one of the six geo political zones in Nigeria, which comprises of six states which are Ekiti, Ondo, Osun, Oyo, Ogun, and Lagos state. The western region is populated mainly by Yoruba ethnic group, with a general language Yoruba which makes them culturally homogenous even in traditional art and culture like pottery, sculpture, mat, basket weaving and traditional festival etc. Although little different are noticeable in dialects of the Yoruba language spoken by the different South-western states of Nigeria.

The Climate is equatorial with distinct wet and dry seasons, it is lowland tropical forest. The dry season last between November and march, while the wet season prevails between April and October with humidity and 
high annual rainfall which varies between $1000 \mathrm{~mm}$ and $1500 \mathrm{~mm}$ with a monthly temperature which range from $18^{\circ} \mathrm{C}$ to $24^{\circ} \mathrm{C}$ during wet Season and at dry season, it ranges from $30^{\circ} \mathrm{C}$ to $35^{\circ} \mathrm{C}$.

South-West Nigeria cover approximately an area of $114,271 \mathrm{~km}$ of approximately $12 \%$ of Nigeria's total land mass and virtually all parts of the southwest have natural lowland vegetation making it typical rainforest zone. The total population is about $27,581,992$ at the census in 2006. Therefore, due to the favorable climate in the zone, the major traditional occupation of the people is farming with various agricultural activities. Crop cultivated are maize, yam, cassava, millet, rice, plantains, cocoa, kola nut, oil palm, cashew etc. (NPC, 2006) and aqua cultural activities like river fishing, fish ponds. Other income generating activities include crafting, trading etc.

Population and Sampling Procedure: - This comprises of all fish farmers in South Western Nigeria. A Purposive sampling procedure was used to select 2 states based on the fact that there are large water bodies for fishing and as a result of the fishing activities in the state/ area. 2 local governments were selected from each state and 2 communities were selected from each local government area while 20 respondents were selected from each community making a total of 160 respondents for the study.

Instrument and Method of Data Collection: - The instruments used for data collection was well structure interview schedule, oral interviews and close observation was administered in selected member of house-hold (160) used for this study. Visitation were made to the selected communities for the administration and collection of questionnaires as well as interviewing the respondents that are non- literate

Method of Data Analysis: - The data collected was analyzed using descriptive statistics such as frequency, percentage, mean and standard deviation. Inferential statistics -chi-square $\left(X^{2}\right)$ was used to test the hypotheses.

\section{Result and Discussion}

\section{Socio - Economic Characteristics of Respondents}

Table 1 revealed the socio-economic characteristics of the respondents. The mean age was 44.8 years, this implies that majority of the respondents are still in their active stage of life and fish farming requires adequate attention and a lot of sense of responsibilities. 35\% constituting the majority of the respondents were in the age range between 41 and 50 years. Fish farming requires strength and vigor in ensuring proper management. It was observed that majority (77.5\%) of the respondents were male, while the remaining (22.50\%) were female. The male dominancy in this source of livelihood implies the laborious nature of fish farming operations right from pond construction to management which their female counterparts cannot easily undertake.

6.9 percent of the respondents were single, while majorities (90.0\%) were married. Only 3.1 percent of the respondents were divorced. Since the marital status of the respondents is a function of their household size, hence, farmers may have reduced cost of production if they employ family labour on their fish farms.

Distribution of respondents by their educational level shows that 7.5 percent of the respondents had no formal education, 16.9 percent had primary education, 36.3 percent had secondary education, and 23.8 percent had tertiary education while 15.6 percent acquired adult education. It can be observed that majority of the respondents are educated and only few had no formal education at all. Fish farming requires a lot of technical and scientific knowledge, the information on the innovations of fish farming is somehow complex and this need some high level of education to practice and the more educated the respondents, the easier it will be for them to decide and process the information. The mean fish farming experience was 8.6years; this connotes that fish farming diffused very slowly among the farmers. But involvement of farmers in fish farming in the last 9 years had greatly increased. Farming experience of respondents could also be an indicator of how they manage risk through trials and errors and their adoption of improved fish farming technologies. The majority (98.1\%) of the respondents engaged fully in fish farming, while the remaining (1.9\%) practiced fish 
farming on part-time basis. it is possible to perceive increased productivity and utilization of extension service delivery among farmers whose mainstay is fish farming: while respondents that engage in other occupation may not have time to manage his farm efficiently. The distribution of respondents based on the type of fish farming method practiced. 15percent practiced fish farming in a concrete pond, while majority (48.8\%) reared fish in an artificial earthen pond. 30.6 percent uses tank (taponlene) to practice fish farming, 3.1 percent practiced fish farming in the wild while 2.5 percent uses artificial lakes. This implies that there are a lot of fish farming methods available to the respondents in the study area, although the social, method and environmental factor could have likely influenced any of this fish farming methods practiced in the study area. Also, 9.4 percent of the respondents did not belong to any social group in their community/area, while the remaining $(90.6 \%)$ belong to one social group or other. This could be due to personal interest and desirable goal aimed at achieving by the respondents. As membership of social group could be an avenue for farmers to share new ideas, innovations or have access to inputs. In the same vein, 20.6 percent were member of cooperative society in their area, 18.10 percent belong to their occupation group (fish farming association) while majority (51.90\%) of the respondents explored the due membership advantages of cooperate society and fish farming group.

Majority (77.5\%) of the respondents had no contact with agent, while only 22.5 percent has access to extension agent. The implication of this is that, the impact of extension agent has not been really felt in the study area. This could be due to the non-challant attitude of the governments toward financing the extension services which leads to their poor performances.

Table 1: - Socio - Economic Characteristics of Respondents

\section{Variables}

Frequency

\section{Percentage}

\section{Age}

Below 31

43

56

34

14

Above 60

Female

\section{Marital status}

Single

Married

Divorced

\section{Educational level}

No formal education

Primary education

Secondary education

Tertiary education 
Adult education

\section{Fish farming experience}

Below 5

11-15

$16-20$

Nature of farming operation

Full time

Part time

\section{Fish farming methods}

Concrete pond

Artificial earthen pond

Tank fishing

Fish in the wild

Artificial

Membership of social group

Yes

No

\section{Social group types}

Nil

Cooperative society

Fish farming association

Cooperative and fish farming group

\section{Extension contact}

Yes

36

No

Source: Field survey, 2014. 


\section{Sources of Information on Fish Farming}

Table 2 shows the distribution of the sources of information on fish farming. The information sources that were frequently utilized were agriculture shows $(75.6 \%)$, bulletin \&handbill $(75 \%)$, and ministry of agriculture (49.4\%). Looking critically at these revealed that farmers utilized information that enable them to see how it works rather than just learning or hearing about how it works. Information sources that were rarely available includes extension agent (50.6\%), farmer association (49.4\%) and NGO's (50.6\%). From this result, most of these information sources available were not frequently utilized. This is of policy implication, government at all levels should make information concerning fish farming production readily available through ICTs (interment, GSM) by subsidizing the cost of accessing the facilities for effectiveness.

Table 2: - Distribution of Respondent by Frequency of available Information

\begin{tabular}{|c|c|c|c|c|}
\hline Information source & Very Frequent (\%) & Frequent (\%) & Rarely (\%) & Not at all (\%) \\
\hline Extension Agent & - & $40(25 \%)$ & $81(50.6 \%)$ & $39(24.4 \%)$ \\
\hline \multicolumn{5}{|l|}{ Farmers/Association } \\
\hline Group & - & $81(50.6 \%)$ & $79(49.4 \%)$ & - \\
\hline Friends /Relatives & $39(24.4 \%)$ & $40(25 \%)$ & $41(25.6 \%)$ & $40(25 \%)$ \\
\hline Workers & - & $81(50.6 \%)$ & $40(25 \%)$ & $39(24.4 \%)$ \\
\hline Radio & - & $119(74.4 \%)$ & $41(25.6 \%)$ & - \\
\hline Newspaper & $40(25 \%)$ & $120(75 \%)$ & - & - \\
\hline Telephone / GSM & $81(50,6 \%)$ & $40(25 \%)$ & $39(24.4 \%)$ & - \\
\hline Agriculture show & $121(75.6 \%)$ & $39(24.4 \%)$ & - & - \\
\hline Bulletin / Handbill & $120(75.0 \%)$ & $40(25 \%)$ & - & - \\
\hline NGO`s & - & $40(25 \%)$ & $81(50.6 \%)$ & $39(24.4 \%)$ \\
\hline $\begin{array}{l}\text { Research } \\
\text { institute/university }\end{array}$ & - & $40(25 \%)$ & - & - \\
\hline Ministry of agriculture & $79(49.4 \%)$ & $81(50.6 \%)$ & - & - \\
\hline Internet & - & $2(1.3 \%)$ & $2(1.3 \%)$ & $156(97.5 \%)$ \\
\hline
\end{tabular}

Source: Field survey, 2014.

\section{Types of Extension Services Received from Extension Agent}

Table 3 shows the distribution of the extension services received by the farmers. Most of those that had access to extension services had information on market (39.4\%), fish harvesting (37.5\%), pond construction (37.5\%), fish preservation (34.4\%), and disease control (31.3\%). This is because these are the most common fish farming operations that are done by the farmers. So, the farmers were eager to get information on these operations. About $29.4 \%$ had information on credit, $26.3 \%$ on drugs, $28.1 \%$ on fingerlings, $26.9 \%$ on feed formation, $25 \%$ on equipment and $12.5 \%$ on spawning. This is because most of these operations were carried out by consultants, so the farmers pay little attention to them. Record keeping is among the least extension services received from the change agents in the study area, this implies that the farmers in the study area lack appropriate information on record keeping and this could be the reason why they lack adequate data on their farming operations. 
Table 3: - Farmers Distribution by the Information Received from Extension Agent

\begin{tabular}{|c|c|c|}
\hline Extension Services & Frequency & Percentage \\
\hline pond construction & 60 & 37.5 \\
\hline feed formulation & 43 & 26.9 \\
\hline Credit facilities & 47 & 29.4 \\
\hline Equipment & 40 & 25.0 \\
\hline New treads & 40 & 25.0 \\
\hline Market information & 63 & 39.3 \\
\hline Drugs & 42 & 26.3 \\
\hline Fingerlings & 45 & 28.1 \\
\hline Storage/Preservation Technique & 55 & 34.4 \\
\hline Fish Harvesting & 60 & 37.5 \\
\hline Storage/Preservation Technique & 60 & 37.5 \\
\hline Spawning operation & 20 & 12.5 \\
\hline Record keeping & 32 & 20.0 \\
\hline Disease control/ treatment & 50 & 31.3 \\
\hline
\end{tabular}

Source: Field survey, 2014

Multiple responses

\section{Constraints to Information Access}

Table 4 shows the problems militating against farmers accessing information through extension service delivery in the study area. The major constraints were inadequate extension contact $(88.8 \%)$, followed by ineffective communication (63.8\%) and high level of illiteracy (34.4\%), thus accessing information, using ICTs such as internets may be very difficult. Distance from one farmer to the other was also a barrier since farmers reside in remote areas, coupled with increased transportation cost making cross fertilization of ideas among farmers very difficult. Format of presentation and language barrier was also identified as factors militating against farmer's access and utilization to information delivery by the farmers. All these cannot be avoided in a country like Nigeria.

Table 4: - Distribution of Respondents by Constraints faced in accessing Information on Fish farming.

\begin{tabular}{lll}
\hline Constraints & Frequency & Percentage \\
\hline
\end{tabular}

Inadequate Extension contact

Ineffective communication
142

102
88.8

63.8 


\begin{tabular}{lcc} 
High cost of material & 89 & 55.7 \\
Distance from other farmers & 41 & 25.7 \\
Format of presentation & 32 & 20.0 \\
Language barriers & 25 & 15.7 \\
Illiteracy & 55 & 34.4 \\
\hline
\end{tabular}

Source: Field Survey, 2014

Multiple responses,

\section{Test of Hypotheses:}

$\mathrm{H}_{01}$ : There is no significant relationship between socio-economic characteristics of fish farmers and extension information delivery and utilization.

The result of the chi-square analysis carried out to test whether or not there is significant relationship between socio-economic characteristics of fish farmers and extension information delivery and utilization received by the farmers shows that the Chi-Square $\left(X^{2}\right)$ calculated is 8.3517 with a probability (P-value) of 0.0007 . The result thus connotes rejection of null hypothesis that there is no significant relationship between socio-economic characteristics of fish farmers and extension information delivery and utilization received in favour of the alternative. Therefore, this is enough evidence from the result to conclude that there is significant relationship between socio-economic characteristics of fish farmers and extension information delivery and utilization.

It thus implies that socio-economic characteristics such as age of the fish farmers, sex, level of education, fish farming experience and social organization/membership of the farmer are germane in determining extension information deliver in the study area. For instance, a fish farmer with B.sc degree might see enough reasons to source for information and as well utilized the information at his/her disposal better or faster than a farmer without any formal education. Likewise, a farmer with more practical experience might see enough reasons to utilize vital information than a farmer with less experience because he/she probably know the aftermath implication of doing so. It therefore means that the extent to which farmers utilize information at their disposal could be influence by their socio-economic characteristics as both maintain a significant relationship.

Table 5: Relationship between socio-economic characteristics and information utilization

\begin{tabular}{llll}
\hline & Value & P-Value & Decision \\
\hline Chi-Square & 8.3517 & 0.0007 & S \\
Likelihood Ratio & 6.218 & & \\
No. of valid class & 160 & & \\
\hline
\end{tabular}

$\mathbf{P}<0.05 \mathrm{~S}=$ Significant

$\mathrm{H}_{02}$ : There is no significant relationship between information sources and extension information delivery and utilization.

Presented in table 6 the result of the Chi-Square analysis carried out to investigate the relationship between information sources and extension information delivery and utilization. The result in table 6 report $X^{2}$ calculated value of 13.426 and a probability value of 0.016 respectively. Because the probability value is less than 0.05 the null hypothesis is rejected in favour of the alternative hypothesis at $5 \%$ significant level. 
Therefore, the studies conclude that there is enough evidence from the chi-square result to believe that there is significant relationship between information source and extension information delivery and utilization.

It thus implies that the source from which information is gathered goes a long way in the level of utilization of such information; this might be as a result of the fact that the sources of information often suggest the validity and authenticity of the information. For instance, information given by an expert e.g. mass media, extension agent, research institutes, might attract better or faster utilization than information coming from non-expert. Therefore, the source of information available to fish farmers is significantly connected with level of utilization.

Table 6: - Relationship between information source and information utilization.

\begin{tabular}{lllll}
\hline & Value & df & P-Value & Decision \\
\hline Chi-Square & 13.426 & 10 & 0.016 & S \\
Likelihood Ratio & 10.117 & & & \\
No. of valid class & 160 & & & \\
\hline
\end{tabular}

\section{$\mathrm{P}<0.5 \quad$ S=Significant}

\section{Conclusion}

It can be concluded from the study that some facts about the impact of extension agents in disseminating information to fish farmers in the study area was established. The socio-economic characteristics of fish farmers in the study area influence their access to extension services. However, respondents utilize information on stocking operation, water treatment, feed formulation technology and operation, and market information storage and preservation techniques. There are still gaps on technologically driven information like spawning operation, new trends in fish management. This could be due to the fact that the trend or technology incomprehensible or culturally incompatible to them. The impact of extension services was not equally felt among respondents, this could be due to lack of adequate mobility to reach some of the farmers by extension agents. Also, most of the fish farmers site their farms in remote areas so as to ensure natural habitat for

$\mathrm{H}_{02:}$ There is no significant relationship between information sources and extension information delivery and utilization.

Presented in table 6 is the result of the Chi-Square analysis carried out to investigate the relationship between information sources and extension information delivery and utilization.

\section{Recommendation}

The following recommendations were made based on the findings.

- Fish farmers should be encouraged to subscribe to various fish farmers group. This will make information and credit facilities accessible to them.

- Fish farmers should also mobilize themselves to form/ establish viable cooperative society in order to enjoy government provision of capital under poverty alleviation scheme.

- The mobility of extension agents must be adequately enhanced for effective coverage, and they should also be updated through in-service training on any new technology for quick dissemination.

- Other method such as mass media should be used regularly to disseminate information to fish farmers.

- Farmers too should also be eager to receive the extension agents and should always search for their help when necessary. 


\section{References}

1. Adamu, B. (2007) "Trade and Investment Opportunity in Agriculture". A paper presented at the India Africa Agric. Food submits in New Delhi, 7-8th March 2007.

2. Adekoya, B. and Miller, J. W. (2004). "Fish Cage Culture in Nigeria: An overview". National Culture Agriculture Focus, 1(5): 1-10

3. Adereti, F.O., Fapojuwo, O. E. and Onasanya, A.S. (2006) "Information Utilization on Cocoa Production Techniques by Framers in Oluyole Local Government Area of Oyo State, Nigeria", European Journal of Social Science, Vol. 3(1) pp. 1-7.

4. Ajana, A. M. (2002) "Overview of highlight and problems of fisheries extension in Nigeria Agriculture", Nigeria's Pioneer Agriculture News Reporting and Trade Promotion Magazine, Vol. 4 (1): pp. 27-32.

5. Amiengheme, P. (2005). "The important of Fish in Human Nutrition." A paper delivered at a Fish Culture Forum, Federal Department of Agriculture and Natural resources, Abuja, Nigeria, 2005.

6. Budak, D. B., Budak, F. and Kacira, O.O, (2010). “Livestock Producers' Needs and Willingne ss to pay for Extension service in Adana Province of Turkey". African Journal of Agricultural Research, 5(11): $1187-1190$

7. CBN (2005). "Central Bank of Nigeria Annual report and Statement of Account".

8. CBN (2010). "Central Bank of Nigeria Annual Report for the Year Ended 31st December, 2010". Pg.251.

9. Esobhawan, A.O. (2007). "Efficiency Analysis of Artisanal Fishery Production in Edo State, Nige ria". Ph. D Thesis Submitted to Department of Agriculture Economics and Extension, Ambrose Alli University, Ekpoma, Nigeria.

10. Esobhawan, A.O., Erie, G.O., Osasogie, D.I, Osifo, A.A and Ogundele, S.L. (2011). "Econometric Analysis of the performance of the Fisheries Subsector in the Nigeria Economy from 1970 to 2008: A Structural Analysis Approach". In: P.O. Erhabor, C.I Ada-Okungbowa, C.O. Emokaro and M.O Abiola (eds) From Farm to Table: Whither Nigeria. Proceedings of 12 th Annual National Conference of National Association of Agricultural Economists (NAAE). Pp224-227.

11. FAO (2000) FAO Fishery Department Country Profile. Nigeria. FID/CP/NIR Rev. 4 March 2000 11pp.

12. Fasasi A. T. (2003) Kenynote address of the programme manager of the Ogun state Agriculture Development Programme (OGADEP), Abeokuta at the 1st Annual Fish Farmer seminar and Training Workshop organized by Fisheries Society of Nigeria (Ogun State Chapter) at OGADEP Abeokuta on July 31st 2003. 6pp.

13. Food and Agriculture Organization (2005). "Nutritional Benefits of Fish". Retrieved on October 2, 2011 from w.fao.org/docrep/168.

14. GreenFacts (2004). "World Fisheries Production". www.greenfacts.org/fisheries/04-utilization. htm. Retrieved on January 13, 2006.

15. Obiekezie, A.I. (1999). "Poverty Alleviation through Fisheries Production: The Way Forward' . Paper presented at the Annual Zonal Workshop of the Research-Farmer-Input-Linkage System, Umu dike, Nigeria. 
16. Rivera, W.M. Cary, J.W. (1997). "Privatizing Agricultural Extension". In:Swanson, B.E., Bentz, R.P. and Sofranko, J.A. (Eds), Improving Agricultural Extension: A Reference Manual. Rome: FAO, pp.203-211.

17. Satia, B. P. (1990) "National Reviews for aquaculture Development in Africa", 29 FAO Fisheries Circular, No.770.29. Rome, FAO. 193pp.

18. Shekara, P.C. (2004). "Status of Private Extension in India". Accessed on 27/11/2012 from http://www.manage.gov.in/pvtext/pvtExt.htm.

19. Tobor. J. G. (1992) "The Fishing Industry in Nigeria. Status and Potential for self-sufficiency in fish production", NIOMR Tech. Paper No 54.

20. World Commission on Environment and Development (WCED) (1987). Our Common Future. New York: Oxford University Press. 